\title{
Education in Psychodermatology: Herpes labialis and genitalis*
}

\author{
M. Augustin \\ Department of Dermatology, University of Freiburg, Germany
}

\section{Definition}

Infection with herpes simplex-virus type I (h. labialis) or II (h. genitalis). New nomenclature: human herpes virus 1 (HHV-1) and 2 (HHV-2). HHV-1 widespread in the population (adults $>95 \%$ seropositive), HHV-2 depending on risk groups: about $10-15 \%$ in general population, $>25 \%$ in sexually promiscuous persons. Endogenous re-infections are typical, frequently based on the same influence factors such as cold, UV light, fever/infections, 'stress' and menstruation.

Coding (ICD-10): B00.100, herpes labialis; A60.010, herpes genitalis.

\section{Clinics}

HHV-1 and -2 are mostly transmitted by skin-to-skin or skinto-mucosa contacts.

Typical findings: erythematous plaque, follow by grouped ('herpetiform') vesicles, erosions, crusts, pustules or - rarely even ulceration and necrosis. Primary infection frequently is associated with painful gingivostomatitis.

Typical signs: burning, painful or itching lesions (prodromal signs), at primary infection also fever, headache, regional lymphadenitis, malaise, myalgia.

Most common sites: perioral, oral mucosa, cheeks, nose tip, fingers (HHV-1), genito-anal area (HHV-2). HHV-1 can also occur on genital sites, HHV-2 in the enoral and perioral area. Complications: HHV-1 and HHV-2 in most cases lead to harmless infections which, however, can be associated with severe reductions of quality of life [12, 31, 32, 35]. Erythema multiforme is a typical, but mostly harmless complication. Se-

"This article is an excerpt from guidelines for psychodermatologic disorders prepared for the German Society for Dermatology (Deutsche Dermatologische Gesellschaft, DDG) vere complications (systemic dissemination) are mostly found in immunocompromized persons, e.g., patients in intensive care, post-transplantation, under immunosuppressive treatment or HIV-positive persons. Eczema herpeticatum can be a severe complication in patients with atopic eczema. HHV-2 acquired intrapartum may lead to severe infections in newborn children.

\section{Dermatological Diagnostics}

Required: Usually clinical diagnosis, extralabial or extragenital involvement possible.

Optional: Where appropriate, smears (Tzanck test on acantholytic giant cells), viral culture, serological diagnostics, immunostatus, clarification of underlying diseases.

\section{Psychosomatic Diagnostics}

For levels of evidence and recommendations (L1-4) see table 1.

\section{Emotional Factors in Onset and Course (L1)}

Emotional stress is known in clinical experience as possible cause of attack in all forms of herpes. Numerous clinical [16, $30]$ and experimental $[3,28,33]$ studies support this. From a psychoneuroimmunological viewpoint, emotional stressors and herpes-exacerbations are closely related [2].

\section{Herpes labialis}

The question whether psychological variables may play a role in eliciting herpes labialis infections has no uniform answer. The estimate of personal success in attaining socially desirable goals, on the other hand, has a negative correlation with the onset of herpes recurrences. Significant connections between

\begin{tabular}{ll}
\hline KARGER & $\oplus$ 2001 S. Karger GmbH, Freiburg \\
Fax +497614520714 & Accessible online at: \\
$\begin{array}{l}\text { E-mail Information@Karger.de } \\
\text { www.karger.com }\end{array}$ & www.karger.com/journals/dps
\end{tabular}


Table 1. Levels of evidence and recommendations (modified after [1, 15])

\begin{tabular}{ll}
\hline Level & Evidence is based on at least ... \\
\hline L1a & ... one systematic review \\
L1b & ... one randomized controlled clinical or experimental study. \\
L2 & ... one non-randomized, but controlled study \\
L3 & ... one uncontrolled, but quasi-experimental study of high \\
& methodological value \\
L4 & ... expert opinion \\
\hline
\end{tabular}

the stressor (everyday stress, life-altering events, anxiety) and a recurrence in the subsequent week were found in a study by Schmidt et al. [29]. By contrast, Luborsky et al. [24] found no psychosomatic relationship in the elicitation of herpes labialis. The experimental elicitation of herpes labialis recurrences in a group of patients who attributed their herpes attacks to disgust could be shown by Buske-Kirschbaum et al. [6]. After a visual presentation of disgusting pictures and objects, 8 of 10 patients in the test group developed a herpes recurrence in the following days, while this was not the case in any of the 10 patients in the control group.

\section{Herpes genitalis}

In a study to evaluate a relationship between stress and emotional well-being on the one hand and the onset of a herpes genitalis recurrence on the other hand, a correlation could be observed between depressive mood and viral infection, but no relationship to the degree of stress [18]. Other authors found psychological factors as predictors for recurrence of genital herpes infections [7, 20-22].

The retrospective casuistic studies also point to psychological triggers in a majority of cases $[11,25]$, but they should be evaluated with caution.

The demonstrated positive influence of various psychosocial interventions on the frequency of recurrence of herpes (see below: Therapy) also confirms the hypothesis of a psychosomatic relationship in a subgroup of patients.

\section{Emotional Problems in Adjustment (L1)}

All herpes illnesses may be accompanied by considerable physical and psychosocial stress [4]. In addition to the discomfort of symptoms like burning, pain and itching, there is stress from the visibility of the lip herpes, limitations in eating and drinking, in body contact and in social activities (public meetings, sometimes on the job). The variable 'sadness' could be associated with the frequency of herpes recurrence in the framework of a prospective study [17].

In herpes zoster, the post-zosteric neuralgias are the greatest persistent stress, with corresponding emotional suffering [13, 27].

\section{Diagnostic Measures}

Obligatory: Discussion with the doctor about the psychosocial situation; exploration of eliciting, improving and exacerbating factors, comorbidity.

Optional: Psychometric inventories (e.g., STAI, SCL-90 or HADS in reference to psychological symptoms, MHF in reference to disease-specific adjustment, FKV with respect to coping, FLQA-H with respect to specific quality of life in herpes).

\section{Therapy}

\section{Dermatological Therapy}

External: Lotio alba, virustatic ointments, wound solutions in mucosal area.

Internal: In severe or relapsing cases virustatics (e.g., Aciclovir, Valciclovir).

\section{Psychosomatic Therapy}

The therapeutic indication exists in that there is a relationship between herpes and emotional stress. This applies to both $\mathrm{h}$. labialis and $\mathrm{h}$. genitalis [23].

\section{Psychosomatic Basic Therapy (L4)}

Consolidation of a therapeutic relationship. Expansion of the causal model of the disease, clarification of the psychosocial effects of the disease, conflict-oriented discussions, relaxation procedures.

\section{Indications for Psychotherapy/Psychopharmacology (L4)}

No herpes-specific indications.

\section{Relaxation (L2)}

To reduce symptoms and for prevention of additional symptoms, stress-reducing measures like autogenic training, relaxation procedures and other behavior-oriented methods may be applied [34]. A decrease in recurrence among patients by means of psychological interventions has been confirmed in one-to-one- and group interventions. Both, combined therapies (relaxation procedures, group therapy, health education) [23] and relaxation procedures alone $[5,19]$ have been reported as successful.

Depth-psychological and Analytical Procedures (L4)

No controlled studies. Use according to general indication criteria for these procedures.

Behavior Therapy (L4)

Participation in self-help groups coupled with cognitive restructuring [26] may help to improve coping. Behavior-therapy induced reduction of anti-HHV-2 titers in HIV-positive men [9]. 
Hypnosis (L3)

No controlled studies. Fox et al. [14] desbribe significant reductions of recurrences for HHV-2 in HIV-positive patients after hypnotherapy. Efficacy analogous to studies of other diseases (e.g., atopic dermatitis) may be assumed.

\section{Psychopharmacology (L4)}

No disease-associated indication.

\section{Training Program and Combination Therapies (L3)}

Intensified consultation had a favorable effect on the recurrence rate in non-controlled studies $[8,10]$

\section{Self-help (L4)}

Participation in self-help groups coupled with cognitive restructuring [26] may help to improve coping.

\section{Patient information}

Several Websites offer good information for patients. This is a selection: Detailed information on h. genitalis, provided by the National Institute of Health (USA, English): www.niaid.nih.gov/factsheets/stdherp.htm

Very comprehensive, updated information on herpes. Includes support groups and FAQs (USA, English): www.herpesalliance.org

Herpes information of the American Academy of Dermatology (USA, English): www.aad.org/pamphlets/herpes.html

Website of the Herpes Viruses Association (HVA) (GB, English): www.herpes.org.uk

Herpes information of the New Zealand Dermatological Society (NZ, English): www.dermnet.org.nz/index.html

Website of the New Zealand Herpes Foundation (NZ, English): www.herpes.org.nz/

Commercial Website with information on H. labialis and genitalis (D, German): www.netdoktor.de/Krankheiten/Fakta/herpes_genitalis.htm Website of the international herpes forum; guidelines, news, congress reports (English): www.ihmf.org/Default.asp

\section{References}

1 Agency for Healthcare Research and Quality (AHCPR) 1992, cited after Centre for Evidencebased Medicine, http://cebrn.jr2.ox.ac.uk/docs/levels.html.

2 Bierman SM: A possible psychoneuroimmunologic basis for recurrent genital herpes simplex. West $\mathrm{J}$ Med 1983;139:547-552.

3 Blondeau JM, Aoki FY, Glavin GB: Stress-induced reactivation of latent herpes simplex virus infection in rat lumbar dorsal root ganglia. J Psychosom Res 1993;37:843-849.

4 Brookes JL, Haywood S, Green J: Adjustment to the psychological and social sequelae of recurrent genital herpes simplex infection. Genitourin Med 1993;69:384-387.

5 Burnette M, Koehn K, Kenyon-Jump R, Hutton K, Stark C: Control of genital herpes recurrences using progressive muscle relaxation. Behav Therapy 1991;22:347

6 Buske-Kirschbaum A, Geiben A, Wermke C, Pirke KM, Hellhammer D: Preliminary evidence for herpes labialis recurrence following experimentally induced disgust. Psychother Psychosom 2001;70:8691.

7 Cohen F, Kemeny ME, Kearney KA, Zegans LS, Neuhaus JM, Conant MA: Persistent stress as a predictor of genital herpes recurrence. Arch Intern Med 1999;159:2430-2436.

8 Connor-Greene PA: The role of counseling in the treatment of genital herpes. J Am Coll Health 1986;34:286-287.

9 Cruess S, Antoni M, Cruess D, Fletcher MA, Ironson G, Kumar M, Lutgendorf S, Hayes A, Klimas $\mathrm{N}$, Schneiderman N: Reductions in herpes simplex virus type 2 antibody titers after cognitive behavioral stress management and relationships with neuroendocrine function, relaxation skills, and social support in HIV-positive men. Psychosom Med 2000;62:828-837.

10 Derman RJ: Counselling the herpes genitalis patient. J Reprod Med 1986;31(Suppl 5):439-444.

11 Dimitrov CT: Psychologische Faktoren bei Herpes Simplex recidivans Genitalis. Z Psychosom Med Psychoanal 1973;19:279-287.
12 Doward LC, McKenna SP, Kohlmann T, Niero M Patrick D, Spencer B, Thorsen H: The internationa development of the RGHQoL: A quality of life measure for recurrent genital herpes. Qual Life Res 1998;7:143-153.

13 Engberg IB, Grondahl GB, Thibom K: Patients' experiences of herpes zoster and postherpetic neuralgia. J Adv Nurs 1995;21:427-433.

14 Fox PA, Henderson DC, Barton SE, Champion AJ, Rollin MS, Catalan J, McCormack SM, Gruzelier J: Immunological markers of frequently recurrent genital herpes simplex virus and their response to hypnotherapy: A pilot study. Int J STD AIDS 1999 10:730-734.

15 German Cochrane Center, 2001, http://www. cochrane.de/deutsch/ccevidenzhierarchie.htm.

16 Glaser R, Kiecolt-Glaser JK, Speicher CE, Holliday JE: Stress, loneliness, and change in herpes virus latency. J Behav Med 1985;8:249-260.

17 Katcher AH Brightman V Luborsky L Ship I: Prediction of the incidence of recurrent herpes labialis and systemic illness from psychological measurements. J Dent Res 1973;52:49-58.

18 Kemeny ME, Cohen F, Zegans LS, Conant MA Psychological and immunological predictors of genital herpes recurrence. Psychosom Med 1989; 51:195-208.

19 Koehn K, Burnette MM, Stark C: Applied relaxation training in the treatment of general herpes. J Behav Ther Exp Psychiatry 1993;24:331-341.

20 Levenson JL, Hamer RM, Myers T, Hart RP, Kaplowitz LG: Psychological factors predict symptoms of severe recurrent genital herpes infection. J Psychosom Res 1987;31:153-159.

21 Longo D, Koehn K: Psychosocial factors and recurrent genital herpes: A review of prediction and psychiatric treatment studies. Int J Psychiatry Med 1993;23:99-117.

22 Longo DJ, Clum GA: Psychosocial factors affecting genital herpes recurrences: Linear vs mediating models. J Psychosom Res 1989;33:161-166.

23 Longo DJ, Clum GA, Yaeger NJ: Psychosocial treatment for recurrent genital herpes. J Consult Clin Psychol 1988;56:61-66.
24 Luborsky L, Mintz J, Brightman VJ, Katcher AH: Herpes simplex virus and moods: A longitudinal study. J Psychosom Res 1976;20:543-548.

25 Luby ED, Klinge V: Genital herpes. A pervasive psychosocial disorder. Arch Dermatol 1985;121: 494-497.

26 McLarnon LD, Kaloupek DG: Psychological investigation of genital herpes recurrence: Prospective assessment and cognitive-behavioral intervention for a chronic physical disorder. Health Psychol 1988;7:231-249.

27 Pilowsky I: Psychological aspects of post-herpetic neuralgia: Some clinical observations. Br J Med Psychol 1977;50:283-288.

28 Rasmussen AF Jr, Marsh JT, Brill NQ: Increased susceptibility to herpes simplex in mice subjected to avoidance-learning stress or restraint. Proc Soc Exp Biol Med 1957;96:183-189.

29 Schmidt DD, Zyzanski S, Ellner J, Kumar ML, Arno J: Stress as a precipitating factor in subjects with recurrent herpes labialis. J Fam Pract 1985;20: 359-366.

30 Smith GR Jr, McKenzie JM, Marmer DJ, Steele RW: Psychologic modulation of the human immune response to varicella zoster. Arch Intern Med 1985;145:2110-2112.

31 Spencer B, Leplege A, Ecosse E: Recurrent genital herpes and quality of life in France. Qual Life Res 1999;8:365-371.

32 Taboulet F, Halioua B, Malkin JE: Quality of life and use of health care among people with genital herpes in France. Acta Derm Venereol 1999;79: 380-384.

33 Ullman M: Herpes simplex and second degree burns induced under hypnosis. Am J Psychiatry 1947;103:828-830.

34 VanderPlate C, Kerrick G: Stress reduction treatment of severe recurrent genital herpes virus. Biofeedback Self Regul 1985;10:181-188.

35 Wild D, Patrick D, Johnson E, Berzon R: Measuring health-related quality of life in persons with genital herpes. Qual Life Res 1995;4:532-539. 